\section{LENGTH-WEIGHT RELATIONSHIP OF CYPRINID FISH, RASBORA DANICONIUS (HAMILTON-BUCHANAN) FROM SHARAVATHI RESERVOIR, KARNATAKA}

\author{
K. Harish Kumar, B.R. Kiran, R. Purushotham, E.T. \\ Puttaiah and S. Manjappa
}

Department of Environmental Science, Kuvempu University, Jnana Sahyadri, Shankaraghatta, Karnataka 577451, India

The study of length weight relationship of fishes have two objectives, (i) to determine the type of mathematical relationship between two variables so that if one variable is known the other could be computed, and (ii) to know the well being of fish and also type of growth, i.e., whether isometric or allometric. Rasbora daniconius (Hamilton-Buchanan) (Cypriniformes: Cyprinidae) is widely distributed in streams, rivers, pools, ponds, tanks and reservoirs of India. It is a popular food fish for economically weak communities because of low price. The present study was aimed at working out the length-weight relationship in both the sexes of Rasbora daniconius from downstream stretch of Sharavathi reservoir, Karnataka.

A total of 70 specimens (52 males and 18 females) of different size groups $(1.7$ to $9.5 \mathrm{~cm})$ were collected from downstream stretch of Sharavathi reservoir $\left(14^{0} 41^{\prime} 24^{\prime \prime} \mathrm{N}-74^{0} 50^{\prime} 54^{\prime \prime} \mathrm{E}\right)$ during August 2004 and June 2005. Length of the fishes were measured and weighed in fresh condition to the nearest $0.1 \mathrm{~mm}$ and $0.1 \mathrm{~g}$, respectively. The length-weight relationship was estimated using the formula $\mathrm{W}=\mathrm{aL}^{\mathrm{b}}$ (LeCren, 1951; Annappaswamy et al., 2004) where, $\mathrm{W}=$ weight of the fish, $\mathrm{L}=$ length of the fish and ' $a$ ' and ' $b$ ' are constants or it can be linearly represented as $\log W=\log a+b \log L$. The constants Log ' $a$ ' and ' $b$ ' in the above equation were estimated using the methods of least square. The linear equation was fitted separately for males and females. The correlation coefficient (r) and regression coefficient (b) were calculated following standard statistical procedures. The ' $t$ ' test was used to test whether the regression coefficient significantly deviated from the expected cubic value (Snedecor \& Cochran, 1967).

The length of males ranged from 1.7 to $6.0 \mathrm{~cm}$ and that of females ranged between 2.5 to $9.5 \mathrm{~cm}$. The weight of females and males varied from 0.21 to $8.10 \mathrm{~g}$ and 0.05 to $2.19 \mathrm{~g}$, respectively. The estimated coefficients of the length-weight relationship and other details of statistical analysis are summarized in Table 1. Scrutiny of ' $r$ ' values and ' $t$ ' test indicated high degree of positive correlation between the variables in both the sexes. Since there was significant difference between the sexes, separate equation for each sex was worked out. The logarithmic relationship between length and weight of males and females is given in Figure 1. The equations derived were:

Males - $\log \mathrm{W}=-1.329+2.640 \log \mathrm{L}$ or $\mathrm{W}=0.0468 \mathrm{~L}^{2.640}$ Females - $\log \mathrm{W}=-1.310+2.498 \log \mathrm{L}$ or $\mathrm{W}=0.0489 \mathrm{~L}^{2.498}$
It is noticeable from Table 1 and Figure 1 that the weight in relation to total length is highly significant in both the sexes of $R$. daniconius. The correlation co-efficient (r) was 0.954 and 0.972 for male and female, respectively, which is higher than the tabulated ' $r$ ' value (Pauly, 1983) at $n-2$ degree of freedom at $1 \%$ level of probability. The calculated ' $t$ ' value was lower than the tabulated value at $5 \%$ probability level for both the sexes. Here, 'b' was 2.640 for males and 2.498 in case of females. Analysis of variance testing the regression of the length-weight relationship in the $R$. daniconius (combined sex) is shown in Table 2.

Generally, weight of the fish will be proportional to the cube of their length, based on its dimensional equality. Beverton and Holt (1957) while discussing the merits of allometric formula $\left(\mathrm{W}=\mathrm{aL}^{\mathrm{b}}\right)$ with cube formula $\left(\mathrm{W}=\mathrm{aL}^{3}\right)$ stated that instance of deviations from isometric growth in adult fishes are rare. Hence, it appears advisable to test the regression coefficients against the isometric growth value of ' 3 ' to find whether there is any significant deviation. The results of analysis showed that (Table 1) in case of both the sexes the ' $b$ ' value was significantly different from ' 3 ' at $1 \%$ level. The results indicated that the length-weight relationship of both the sexes do not followed cube law. Total weight of fish may also be altered by the weight of the stomach content depending on the food of stomach content depending on the food ingested just before weighing (Muth \& Smith, 1974). The divergence from the cube law may be due to certain environmental factors also. Pathak (1975) reported that the ' $b$ ' values less than ' 3 ' in Labeo calbasu of Soni reservoir. Mercy et al. (2002) reported that the ' $b$ ' value (3.04) in Puntius denisonii of Bharathapuzha river system in Kerala also followed cube law. Sunil Kumar et al. (1999) opined that the exponential values for Horabagrus brachysoma do not significantly differ from ' 3 '.

Depending on the deviation of $b$ values from ' 3 ' fishes can be classified in to three groups (a) $b=3$ where the body form of fish remains constant (isometric) at different lengths (Allen, 1938) (b) $b<3$ when fish becomes more slender as the length increases and (c) $b>3$ when fish grows more stouter with increase of length (allometric). But the value of ' $b$ ' usually remains between 2.5 and 4.0 (Hile, 1936; Martin, 1949). The present value ranged between 2.498 and 2.640. Thus in the current study, weight in relation to total length in both the

Table 1. Coefficient of length weight relationship and statistical analysis of Rasbora daniconius

\begin{tabular}{llllll}
\hline Sex & $\begin{array}{l}\text { No of } \\
\text { fishes }\end{array}$ & A & B & $\mathbf{Y}=\mathbf{a}+\mathbf{b} \mathbf{x}$ & $\mathbf{r}$ \\
\hline Females & 18 & -1.310 & 2.498 & $\mathrm{Y}=-1.310+2.498 \times$ & $0.972^{*}$ \\
Males & 52 & -1.329 & 2.640 & $\mathrm{Y}=-1.329+2.640 \times$ & $0.954^{*}$ \\
\hline
\end{tabular}

* Significant $(P<0.01)$

Table 2. Analysis of variance testing the regression of the length-weight relationship in Rasbora daniconius

\begin{tabular}{llll}
\hline Variables & DF & Sum of squares & Mean square \\
\hline Total length & Regression 1 & 2.901 & 2.901 \\
& Residual 68 & 0.232 & 0.002 \\
\hline
\end{tabular}

F - 835.076; Significance of F - 0.000

(C) Zoo Outreach Organisation; www.zoosprint.org tober 2005: Date of publication 21 December 2005 

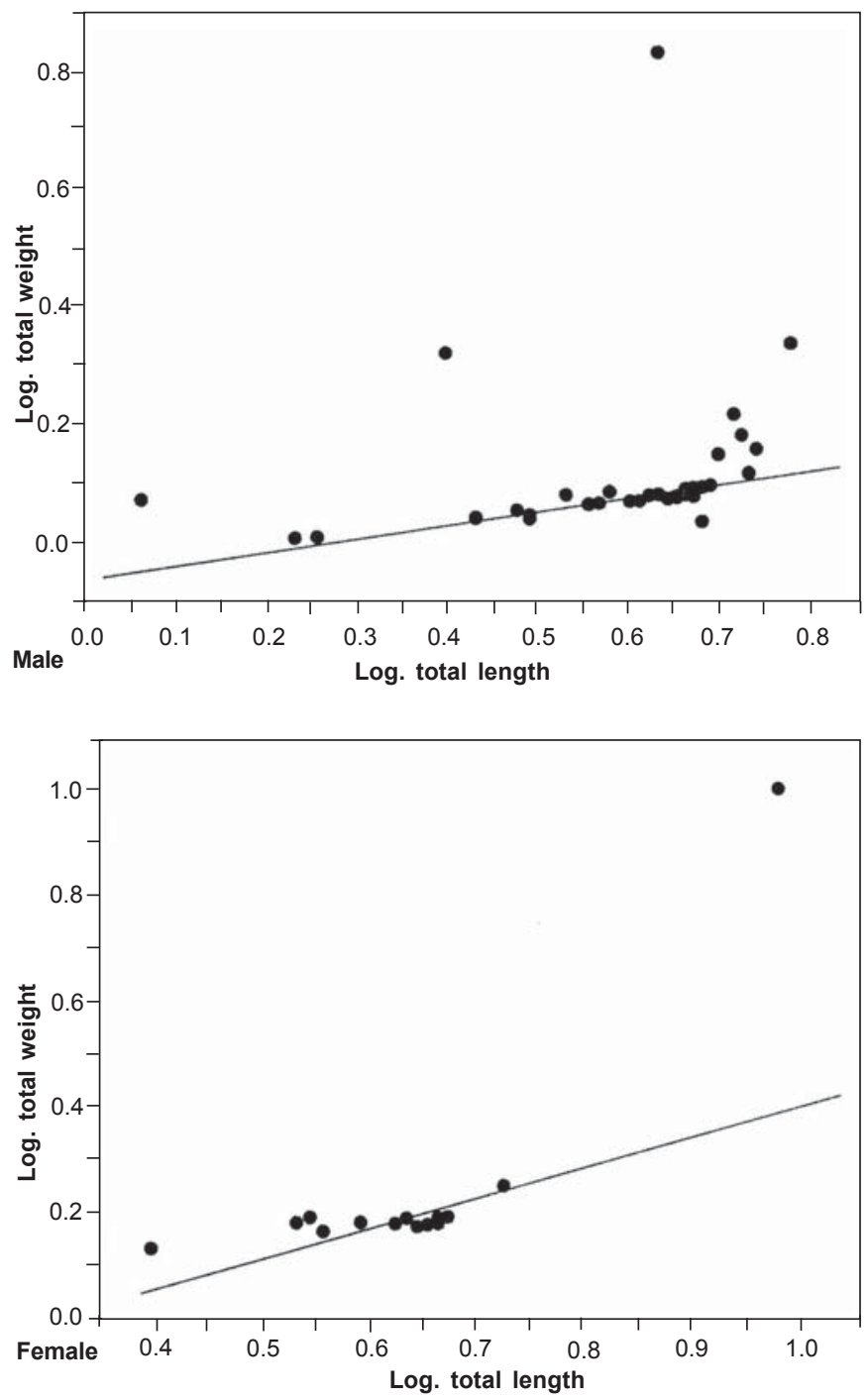

Figure 1. Logarithmic relationship between total lengthweight of Rasbora daniconius.

sexes of $R$. daniconius follow 'allometric' growth pattern.

\section{REFERENCES}

Allen, J.D. (1938). Some observation on the biology of the trout, Salmo trutta in Windermere. Journal of Animal Ecology 7: 333-348. Mercy, T.V.A., K.R. Thomas and E. Jacob (2002). Length-weight relationship in Puntius denisonii (Day). Indian Journal of Fisheries 49(2): 209-210.

Annappaswamy, T.S., H.R.V. Reddy and T.S. Nagesh (2004). Lengthweight relationship of Indian sand whiting, Sillago sihama (Forskal) in Mulki estuary, Mangalore. Journal of Inland Fisheries Society of India 36(1): 18-22.

Beverton, N.J.H. and S.J. Holt (1957). On the dynamics of exploited fish populations. Fish Investigation. London series 2, 19: 1-533.

Hile, R. (1936). Age and growth of the Cisco leucichthys artedi (Le sueur) in the lake of North eastern highlands Wisconsin. Bulletin of the United States Bureau of Fisheries 48: 311-317.

LeCren, C.D. (1951). The length-weight relationship and seasonal cycle in gonad weights and condition in perch, Perca fluviatilis. Journal of Animal Ecology 20: 201-209.
Martin, W.R. (1949). The mechanics of environmental control of body from in fishes. University of Toronto Studies in Biology 70: 1-97. Muth, K. and L.L. Smith (1974). The Barbut fishery in lake of the woods. Technical Bulletin 296: 1-33.

Pathak, S.C. (1975). Length-weight relationship, condition factors and food study of Labeo calbasu (Hamilton) from Soni reservoir (Madhya Pradesh). Journal of Inland Fisheries Society of India 8: 58-64.

Pauly, D. (1983). Some simple methods for the assessment of tropical fish stocks. FAO Fisheries Technical Paper 234: 1-52.

Snedecor, C.W. and W.G. Cochran (1967). Statistical Methods. Oxford and IBH Publishing Company, New Delhi, 435pp.

Sunil Kumar, G., T.V.A. Mercy and K.C. John (1999). Lengthweight relationship in the catfish Horabagrus brachysoma (Gunther). Indian Journal of Fisheries 46(2): 191-193.

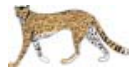

VET BRIEF

ZOOS' PRINT JOURNAL 21(1): 2141-2142

\section{ANCYLOSTOMIASIS IN DHOLES CUON ALPINUS}

\section{K. Devaki ${ }^{1}$, K. Senthilkumar ${ }^{1}$, Pathan Nasrullahkhan ${ }^{2}$ and M.G. Jayathangaraj ${ }^{3}$}

${ }^{1}$ Veterinary Assistant Surgeon, ${ }^{2}$ Veterinary officer, Arignar Anna Zoological Park, Vandalur, Tamilnadu

${ }^{3}$ Associate Professor, Department of Wildlife Sciences, Madras Veterinary College, Vepery, Chennai 600007, Tamil Nadu

The Dhole or the Indian Wild Dog (Cuon alpinus) is a highly social canid. Puppies are completely dependent on their mother for milk and on the rest of the pack for regurgitated food for the first few months of their lives.

A Dhole at the Arignar Anna Zoological Park, Chennai gave birth to nine pups which were well cared by the mother. Faecal samples were collected from all the nine pups using sterile cotton swabs at the age of 20 days. Ancylostoma eggs were observed using floatation method within two hours and eggs per gram were evaluated using modified McMaster method (Thienpont et al., 1986). Eggs were identified by their morphological structure (Soulsby, 1982)

All the pups and the mother were dewormed with pyrantel pamoate@ $9 \mathrm{mg} / \mathrm{kg}$ body wt., mixing the drug in beef for the adult and manually administering the drug to the pups. Coprological examination was carried out after 15 days of administration of the drug. All pups had normal appetite but were weak with rough hair coat before the administration of pyrantel paomate. On the day prior to administration of pyrantel paomate, all pups had Ancylostoma caninum infection. On day two to day five random faecal examination revealed the presence of eggs of $A$. caninum. The hairs regained the shine in 15 days. A. caninum eggs decreased by $94.2 \%$ on day 15

(C) Zoo Outreach Organisation; www.zoosprint.org Manuscript 1404; Received 19 July 2005; Finally accepted 08 December 2005; Date of publication 21 December 2005 